\title{
FILSAFAT EMANASI IBNU SINA
}

\author{
Kamaruddin Mustamin ${ }^{1}$ \\ ${ }^{1}$ IAIN Sultan Amai Gorontalo, Indonesia, kamaruddinmustamin@gmail.com
}

\begin{abstract}
The development of thought in Islamic teachings has always been colored and colored by other scientific disciplines throughout the history of the course of science. Almost all of them can be said to have been inspired by the search for truth and for God as an "untouchable" substance. Ibn Sina, who is better known as Avicenna, is an important figure in the study of Islamic thought who has sparked theories about the God-man-nature relationship. Through the theory of emanation, Ibn Sina rearranged creative reasoning to keep God's holiness. Through the philosophy of the soul, Ibn Sina describes the human potential who is in choices that limit human value. Through his prophetic philosophy, Ibn Sina describes the human potential who can be closer to God through the figure of "God's choice". Meanwhile, through the philosophy of existence, Ibn Sina was once again able to raise a positive human image that was able to reach the essence in the mind and capture the form outside the human mind. Ibn Sina's creative reasoning made him a figure respected by friends and foes in his time. The traces of Ibn Sina's thoughts today are still an inspiration to every Muslim thinker who acknowledges the unlimited reach of human reason.
\end{abstract}

\section{Keywords: Ibnu Sina, Emanation, Philosophy}

Abstrak: Perkembangan pemikiran dalam ajaran Islam selalu diwarnai dan mewarnai disiplin keilmuan lainnya sepanjang sejarah perjalanan ilmu pengetahuan. Semuanya hampir dapat dikatakan terinspirasi dari upaya pencarian kebenaran dan pencarian Tuhan sebagai zat yang "tak tersentuh". Ibnu Sina yang lebih dikenal dengan sebutan Avicena adalah salah seorang tokoh penting dalam studi pemikiran Islam yang telah mencetuskan teori-teori tentang hubungan Tuhan-manusia-dan alam. Melalui teori emanasi, Ibnu Sina kembali menyusun nalar kreatif untuk tetap menjaga kekudusan Tuhan. Melalui falsafah jiwa, Ibnu Sina mendeskripsikan potensi manusia yang berada pada pilihan-pilihan yang membatasi nilai kemanusiaan. Melalui falsafah kenabian, Ibnu Sina mendeskripsikan potensi manusia yang dapat lebih dekat kepada Tuhan melalui sosok "pilihan Tuhan". Sedangkan melalui falsafah wujud, Ibnu Sina sekali lagi mampu mengangkat citra positif manusia yang mampu menjangkau esensi di dalam akal dan menangkap wujud di luar akal manusia. Kreativitas nalar yang dimiliki Ibnu Sina menjadikannya tokoh yang disegani oleh kawan maupun lawan di masa-Nya. Jejak-jejak pemikiran Ibnu Sina hingga saat ini masih tetap menjadi inspirasi bagi setiap pemikir Muslim yang mengakui keluasan jangkauan nalar manusia yang tidak terbatas.

Kata Kunci: Ibnu Sina, Emanasi, Falsafah 


\section{FARABI}

Jurnal Pemikiran Konstruktif Bidang Filsafat dan Dakwah

ISSN $1907-0993$

E ISSN $2442-8264$

Vol. 16 No. 1, Juni 2019

\section{A. PENDAHULUAN}

Agama Islam yang bersumber dari wahyu Allah mengandung kebenaran, sementara filsafat juga mengandung kebenaran walaupun kebenarannya berdasarkan pencarian nalar manusia. Dengan demikian, agama dan filsafat memiliki ujung yang sama, yaitu "kebenaran". Agama membawa kebenaran sementara filsafat mencari kebenaran, namun kebenaran agama tidak akan dapat dirasakan kecuali orang yang berakal, oleh sebab itu kebenaran agama harus digali agar lebih jelas dan penggaliannya ini dilakukan dengan menggunakan nalar filsafat. Dengan demikian, tidak dapat dipungkiri bahwa Islam sebagai agama wahyu telah memberikan sumbangan besar bagi pertumbuhan dan perkembangan dunia ilmu pengetahuan di Barat. Meskipun umat Islam secara tidak langsung banyak terpengaruh oleh dunia filsafat Yunani, keorisinilan pemikiran para filosof Islam tetap memiliki pengaruh dalam pemikiran filsafat.

Salah seorang filosof Islam abad pertengahan yang sangat cemerlang adalah Ibnu Sina. Ia sangat disegani dan mendapat tempat yang istimewa dalam sejarah perjalanan dan perkembangan filsafat hingga abad modern ini. Ibnu Sina telah membangun sistem filsafat Islam dengan sempurna dan terperinci.

\section{B. BIOGRAFI IBNU SINA}

\section{a. Asal usul kelahiran Ibnu Sina}

Ibnu Sina dilahirkan dalam masa kekacauan dan kemunduran Daulat Bani Abbasiyah di mana daerah-daerah yang pada awalnya berada di bawah kekuasaan Khalifah Abbasiyah, mulai melepaskan diri satu persatu untuk berdiri sendiri, sementara kota Bagdad sendiri sebagai pusat pemerintahan Khalifah Abbasiyah telah dikuasai oleh Golongan Bani Buwaihi pada tahun 334 H. yang kekuasaannya berlangsung sampai tahun $447 \mathrm{H}$. Demikian pula daerah Daulat Samani di Bukhara telah berdiri sendiri dan salah satu khalifahnya adalah Nuh $b$. Mansur, yang pada masanya inilah, di suatu tempat di daerah Bukhara yang bernama Afsyana, lahir dan tumbuh seorang bayi yang bernama Ibnu Sina (370 H/980 M) (Hanafi, 1976:168).

Ibnu Sina merupakan tokoh pemikir muslim yang banyak menguasai bidang ilmu pengetahuan (baik itu ilmu-ilmu agama, sains, kedokteran dan 


\section{FARABI}

Jurnal Pemikiran Konstruktif Bidang Filsafat dan Dakwah

ISSN $1907-0993$

E ISSN $2442-8264$

Vol. 16 No. 1, Juni 2019

humaniora) Ibnu Sina nama lengkapnya adalah Ali al-Husien bin Abdullah alHasan bin Ali bin Sina. Ia dilahirkan di desa Afsyanah, dekat Bukhara, di kawasan Asia Tengah pada tahun $370 \mathrm{H}$ dan meninggal dunia di Hamadzan pada tahun $428 \mathrm{H}$ (1038 M) dalam usia 57 tahun. ${ }^{1}$ dan di negara-negara barat namanya lebih dikenal dengan sebutan Avicena. Ia dilahirkan di Persia pada bulan Syafar 370 H/980 M. Namun orang Turki, Persia dan Arab mengklaim Ibnu Sina sebagai bangsanya. Hal ini dikarenakan ibunya berkebangsaan Turki, sedangkan ayahnya peranakan Arab. Ayahnya tinggal di kota Balkh, tetapi beberapa tahun setelah lahirnya Ibnu Sina, keluarganya pindah ke Bukhara karena ayahnya menjadi gubernur di suatu daerah di salah satu pemukiman Daulat Samaniyah pada masa pemerintahan Amir Nuh ibn Mansur. ${ }^{2}$

\section{b. Pendidikan dan Perjalanan Hidupnya}

Selain belajar secara otodidak, Ibnu Sina juga di didik di bawah tanggung jawab seorang guru. Sumber sejarah hanya sedikit yang menyebutkan guru-guru Ibnu Sina, di antaranya yaitu Ismail al-zahid yang mengajarkannya akhlak, tasawuf, dan fiqih. Kemudian Abu Abdullah al-Natalie yang mengajarkannya dalam bidang logika dan matematika. ${ }^{3}$ Dan Ibnu Sina menguasai ilmu kedokteran hanya dalam waktu satu setengah tahun pada gurunya Isa bin Yahya. ${ }^{4}$

Dia mulai belajar pada usia dini,5 tahun. ${ }^{5}$ Pada usia 10 tahun ia telah menyelesaikan pelajaran al-Qur'an, sastra dan bahasa Arab, Pada usia 10 tahun ia telah hafal al-Qureean dan sebagian besar sastra Arab, serta menjadi pakar puisi Persia. Setelah ditinggal wafat oleh gurunya Abdullah Natalie, Ibnu Sina mengkaji dan mencari ilmu sendiri, seperti dari seorang tukang sayur dia belajar

\footnotetext{
${ }^{1}$ Philip K. Hitti, History of The Arab, (ed). X (Great Britain: Oxford University Press, 1974), hlm. 367

${ }^{2}$ Muhammad Tolhah Hasan, Dinamika Pemikiran tentang Pendidikan Islam (Jakarta: Lantabora Press, 2006), hlm.116

${ }^{3}$ Hasyimsyah Nasution, Filsafat Islam, (Jakarta: Gaya Media Pratama, 1999), h. 67.

${ }^{4}$ Husain Heriyanto, Menggali Nalar Saintifik Peradaban Islam..., h. 199.

${ }^{5}$ Muhammad Nur Effendi, Cendekiawan Muslim: Pembina Tamadun dan Kecemerlangan Umat, Cet. 1, h.152.
} 


\section{FARABI}

Jurnal Pemikiran Konstruktif Bidang Filsafat dan Dakwah

ISSN $1907-0993$

E ISSN $2442-8264$

Vol. 16 No. 1, Juni 2019

mempelajari aritmatika, dan mulai belajar ilmu lainnya dari seorang sarjana yang mempunyai mata pencarian merawat orang sakit dan mengajar anak muda. ${ }^{6}$

Pada usia 16 tahun, Ibnu Sina sudah mahir dalam ilmu kedokteran, sampai-sampai banyak orang yang berdatangan untuk berguru kepadanya. Ia tidak cukup dengan teori-teori kedokteran, tetapi juga melakukan praktek dan mengobati orang-orang sakit, kemudian ia kembangkan teori yang diperolehnya dengan pelbagai percobaan empiris melalui pengobatan orang sakit. ${ }^{7}$ Kemudian ia belajar ilmu fiqh pada seorang guru bernama Ismail yang terkenal sebagai orang yang hidup zuhud. Di samping itu, ia belajar metematika dan ilmu ukur pada 'Ali Abu 'Abdullah an- Natili. Setelah itu ia belajar sendiri dengan membaca berbagai buku, termasuk buku Syarh sehingga menguasi ilmu semantik. Tidak ketinggalan pula ia mempelajari buku Ocledus mengenai ilmu ukur dan buku-buku tentang ilmu kedokteran. Dalam usia 18 tahun ia telah selesai mempelajari semua ilmu tersebut. $^{8}$

Ibnu Sina juga seorang yang ahli dalam bidang ketatanegaraan, sehingga dalam usia 18 tahun beliau telah sibuk dengan urusan negara, memberi kuliah sebagai guru, menjadi filosof dan penyair serta menjadi seorang pengarang yang produktif dalam berbagai lapangan ilmu pengetahuan, seperti filsafat, kedokteran, kenegaraan, perbintangan, pasti, musik, bahasa, ukur, ketuhanan dan sebagainya. Bahkan tak kalah pentingnya konsep beliau tentang pendidikan. Karena keahliannya dalam berbagai bidang ilmu pengetahuan tersebut, sehingga beliau dikenal di dunia Barat dengan nama Avicenna dan mereka sebut dengan “Aristoteles Baru”. Sedangkan di Arab dikenal dengan nama Syeikh al-Rais. ${ }^{9}$

Pada usianya 22 tahun, ayahnya wafat. Ibnu Sina meninggalkan Bukhara menuju Jurjan, kemudian ke Khawarizm, akibat kekacauan politik ia berpindah dari suatu daerah ke daerah lainnya akhirnya sampai ke Hamazan. Oleh Syamsuddaulah, penguasa daerah ini, ia diangkat menjadi menteri beberapa kali,

\footnotetext{
${ }^{6}$ Saharawati Mahmouddin, Sistem Kedokteran Islam: Studi Konsep Kesehatan Mental Ibnu Sina, h. 115.

${ }^{7}$ Abu Ahmadi, Filsafat Islam, Thoha Putra, Semarang, 1982

${ }^{8}$ Ahmad Fuad al- Ahwani, Filsafat Islam (Jakarta: Pustaka Firdaus, 1997), hlm. 84

${ }^{9}$ Philip K Hitti, History of The Arab..., Loc.cit, hal. 367
} 


\section{FARABI}

Jurnal Pemikiran Konstruktif Bidang Filsafat dan Dakwah

ISSN $1907-0993$

E ISSN $2442-8264$

Vol. 16 No. 1, Juni 2019

dan akhirnya ia pindah ke Isfahan dan mendapatkan sambutan yang istimewa dari penguasa daerah ini ${ }^{10}$ Banyak sejarawan yang memuji kecemerlangan prestasi ilmiah yang dicapai Ibnu Sina, tidak seorang pun yang memungkiri kecerdasan otaknya yang luar biasa serta daya ingatnya yang amat kuat. Menurut George Sarton, ia adalah ilmuwan paling terkenal dan filsuf Islam terbaik dari semua ras, tempat dan waktu. ${ }^{11}$ Dia selanjutnya mempelajari ilmu fisika dan ketuhanan, sehingga namanya menjadi popular lantaran kepiawaiannya pada bidang tersebut.

Setelah berhasil dalam pelajaran-pelajarannya secara baik, ia mempelajari ilmu pengetahuan alam, metafisika, yang di dalamnya terdapat Metafisika-nya Aristoteles (Metaphysics of Aristotle), yang sekalipun ia telah membacanya beberapa kali dan menghafalnya, tetap saja ia mengalami kesulitan untuk menghafalnya, sehingga dalam waktu satu setengah tahun Ibnu Sina berkonsentrasi membaca agar mendapatkan pelajaran dan ilmu pengetahuan. Akhirnya buku itu dapat difahaminya ketika membaca buku karangan Al-Farabi. ${ }^{12}$ Abu Nasr Al-Farabi (258-339 H/ 870-950 M) adalah filsuf besar peripatik kedua setelah Al-Kindi (185-260 H/801-873 M). Lahir di daerah Farab, daerah Transoxania. Dalam bidang filsafat Al-Farabi merupakan komentator besar Muslim pertama terhadap filsafat Aristoteles. Dan salah satu karya Al-Farabi yang terkenal adalah Kitab al-Jam' bain Ra'yay al-Hakimain Aflathun al-Ilahi wa Aristhu (Buku tentang Penggabungan antara Pendapat Dua Ahli Hikmah Plato Ilahi dan Aristotelian yang merupakan komentar atas buku Aristoteles. Dia kembali mengkaji logika dan seluruh cabang filsafat, sehingga menguasai seluruhnya. Uniknya juga jika mengalami kesulitan dalam menjawab sebuah masalah atau pertanyaan, maka dia berwudhu dan pergi ke masjid untuk shalat dan berdoa kepada Allah agar diberi kemudahan dalam menjawabnya. Dan pada larut malam dia melanjutkan belajarnya, bila rasa kantuknya datang atau badannya terasa letih, dia minum secangkir hingga timbul kembali kesegarannya. Tetapi jika

\footnotetext{
${ }^{10}$ Hanafi, 1976, hal. 169

${ }^{11}$ M. Saeed Sheikh, Islamic Philosophy, (London: The Octagon Press Ltd, 1982), h. 67.

${ }^{12}$ Didin Saifuddin, Zaman Keemasan Islam: Rekontruksi Sejarah Imperium Dinasti Abbasiyah, h. 188 dan Seyyed Hossein Nasr, Tiga Madzhab Utama Filsafat Islam, h.36-37.
} 


\section{FARABI}

Jurnal Pemikiran Konstruktif Bidang Filsafat dan Dakwah

ISSN $1907-0993$

E ISSN $2442-8264$

Vol. 16 No. 1, Juni 2019

kantuk tidak tertahankan, Ibnu Sina tertidur dan bermimpi tentang soal-soal itu biasanya menjadi terang masalahnya. ${ }^{13}$

\section{c. Karya-karya Ibnu Sina}

Kesungguhannya yang luar biasa dalam mencari ilmu dan bekerja. Siangnya ia gunakan untuk mencari nafkah dan malamnya ia habiskan untuk bertafakur. Ia sering kali tampak dimasjid, berdoa, beribadah dan membaca. Diriwayatkan bahwa ia pernah membaca empat puluh kali buku metafisika karangan Aristoteles, tetapi tidak dipahaminya. Kebetulan ada pedagang buku yang menawarkan buku bekas kepadanya dengan harga sangat murah, lalu ia beli setelah menolaknya beberapa kali. Alangkah gembiranya Ibn Sina setelah diketahui bahwa buku itu adalah karya al-Farabi. Lalu ia baca, sehingga dengan mudah ia memahami buku Aristoteles tersebut dan semuanya ia hafal. ${ }^{14}$

Karya Ibn Sina sangat banyak dan kelengkapan risalahnya jauh melampaui risalah manapun yang pernah dihasilkan pengarang-pengarang filsafat pertama seperti al-Kindi dan al-Razi. G. C. Anawati sorang sarjana Dominican, telah menyusun daftar kitab-kitab Ibn Sina dari 276 tulisan dalam bentuk buku maupun manuskrif. ${ }^{15}$

Dari sekian banyak karya Ibnu Sina, tentu ada karya-karya yang dianggap populer yang membuat nama Ibnu Sina menjadi terkenal dalam kancah ilmu pengetahuan, terutama di dunia Barat. Dalam hal ini, Ahmad Daudi mengatakan ada empat di antara karya Ibnu Sina yang terpenting, antara lain:

1. Al-Qanun fi al-Tibb buku ini sangat tebal dan terdiri dari lima jilid. Kitab ini adalah buku yang berisi tentang ilmu kedokteran, orang Barat menyebut buku ini dengan Canon of Medicine. Buku ini telah diterjemah oleh Gerard of Cremona pada abad ke-11 dengan judul Canon yang diterbitkan di Roma pada tahun 1593, telah pula diterjemahkan ke dalam bahasa latin dan bahasa-bahasa Eropa lainnya dan menjadi literatur pokok di Universitas-universitas di Eropa sampai akhir abad ke-17 dan sampai kini menjadi manuskrif bidang kedokteran

\footnotetext{
${ }^{13}$ Muhammad Nur Effendi, Cendekiawan Muslim: Pembina Tamadun dan Kecemerlangan Umat, h.153-155.

${ }^{14}$ Majid Fakhri, Sejarah Filsafat Islam, (Jakarta : Pustaka Jaya, 1986), hal. 192

${ }^{15}$ Anawati, Essai de Bibliographhie Avicenniene, dalam buku Majid Fakhri, h. 193
} 


\section{FARABI}

Jurnal Pemikiran Konstruktif Bidang Filsafat dan Dakwah

ISSN $1907-0993$

E ISSN $2442-8264$

Vol. 16 No. 1, Juni 2019

yang tersimpan rapi di perpustakaan Birmingham, Inggris bersama dengan Kitabkitab lainnya. ${ }^{16}$

2. sy-Syifa, kitab ini adalah buku filsafat yang terpenting dan terbesar dari Ibnu Sina yang terdiri dari ilmu logika, geometri, fisika dan matematika dan sekaligus dijadikan sebagai ensiklopedi dalam bidang filsafat, fisika, metafisika (ketuhanan), logika dan metematika. ${ }^{17}$ Buku tersebut mempunyai beberapa naskah yang terbesar diberbagai perpustakaan baik di Barat maupun Timur. Buku ini telah dicetak pertama kali di Taheran pada tahun 1303 H. Pada tahun 1956 Lembaga Keilmuan Cekoslowakia di Praha menerbitkan pasal keenam dari bagian fisika yang khusus mengenai ilmu jiwa yang diterjemah ke dalam bahsa Prancis di bawah asuhan Jean Pacush. Bagian logika diterbitkan di Kairo pada tahun 1954 dengan nama al-Burhan dibawah bimbingan Dr. Abdurrahman Badawi. ${ }^{18}$

3. An-Najat, kitab ini merupakan ringkasan dari buku asy-Shifa dan pernah diterbitkan secara besama-sama dengan buku al-Qanun fi al-Tibb dalam ilmu kedokteran pada tahun 1593 M di Roma dan pada tahun $1331 \mathrm{M}$ di Mesir dan juga di India pada tahun $1892 .{ }^{19}$ Buku ini disusun kembali oleh Ibnu Sina untuk memberi penjelasan secara lebih luas dan sistematis tentang asy-Syifa yang diberi kita al-Najatcd atau kitab penyelamat. ${ }^{20}$ Kitab ini jauh lebih banyak dibaca daripada al-syifa, dan ditulis bagi orang-orang terpelajar yang ingin mengetahui dan memahami dengan lengkap dasar-dasar ilmu hikmah.

4 Kitab al-Isyarat wa al-tanbihat, adalah kitab terakhir yang ditulis Ibn Sina, hasil dari satu fase yang lebih independent dalam perkembangan intelektualnya. Dan buku yang paling indah dalam ilmu hikmah. Isinya mengandung berbagai mutiara dari berbagai ahli pikir dan rahasia yang sangat berharga yang sulit ditemui dari buku-buku lainnya. Antara lain uraiannya mengenai logika dan hikmah serta kehidupan dan pengalaman ruhani, dicetak di Leiden pada tahun $1892 .^{21}$

\footnotetext{
${ }^{16}$ Philip K. Hitti, Op.cit, hal. 368

${ }^{17}$ Pembinaan Perguruan Tinggi Agama IAIN Ar-Raniry, Pengantar filsafat..., h.72

${ }^{18}$ A. Hanafi, Pengantar filsafat Islam..., hal. 1, 71-72

${ }^{19}$ Pembinaan Perguruan Tinggi Agama IAIN Ar-Raniry, loc.cit

${ }^{20}$ Sudarsono, Filsafat Islam..., hal. 44.

${ }^{21}$ Ahmad Daudy, Kuliah FilsafatIslam, (Jakarta, Bulan Bintang, cet. Ke-3, 1992) h. 69.
} 


\section{FARABI}

Jurnal Pemikiran Konstruktif Bidang Filsafat dan Dakwah

ISSN $1907-0993$

E ISSN $2442-8264$

Vol. 16 No. 1, Juni 2019

\section{PEMIKIRAN FILSAFAT IBNU SINA}

Salah seorang filosof Islam abad pertengahan yang sangat cemerlang adalah Ibnu Sina. Ia sangat disegani dan mendapat tempat yang istimewa dalam sejarah perjalanan dan perkembangan filsafat hingga abad modern ini. Ibnu Sina telah membangun sistem filsafat Islam dengan sempurna dan terperinci.

Dengan ketajaman otaknya, ia dapat menguasai filsafat dan berbagai cabangnya, walaupun ia harus menunggu saat yang tepat untuk menyelami ilmu metafisika Aristoteles, meskipun ia telah membacanya 40-an kali. Setelah ia membaca buku Agrâd Kitâb mâ' warâ' al-T abî'ah li Aristû-nya Al-Fârabî (870950 M.), seakan-akan semua persoalan telah ditemukan jawabannya dengan terang-benderang. Ia bagaikan mendapatkan kunci bagi segala simpanan ilmu metafisika. Hal inilah yang membuatnya dengan tulus mengakui dirinya sebagai murid yang setia dari Al-Fârabî (Dasuki, 1993:34).

Corak pemikiran Ibnu Sina dalam mengembangkan filsafatnya, beliau memadukan antara filsafat dan agama. Dalam hal ini, M. Natsir mengatakan sosok Ibnu Sina merupakan salah satu muslim yang kreatif yang tidak mengenyampingkan ajaran Islam dalam corak pemikirannya, sekalipun beliau seorang filosuf yang dikagumi pada masanya. ${ }^{22}$

Bahkan kalau kita mau menelaah secara lebih jauh tentang hasil karyanya, nampaknya Ibu Sina begitu rasional, dan tidak mengeyampingkan al-Qur'an dan hadis. walaupun lingkungan masyarakat yang mengitarinya menganut paham Syiah Ismailiyah, namun beliau tidak terpengaruh dengan pemikiran tersebut, bahkan beliau mengembangkan pemikiran dengan caranya sendiri untuk mencari suatu kebenaran (begitulah cara berfikir filosof tidak mau taqlid terhadap pendapat sesuatu). Jadi, kita dapat mengatakan bahwa pada diri Ibnu Sina terdapat perpaduan yang serasi antara aqli dan naqli.

1. Falsafah Emanasi (al-Fayd)

${ }^{22}$ M. Natsir , "Islam dan Kebudayaan” Jurnal Kapita Selekta, Cet. III. (Jakarta: Bulan Bintang, 1973), hal. 2 


\section{FARABI}

Jurnal Pemikiran Konstruktif Bidang Filsafat dan Dakwah

ISSN $1907-0993$

E ISSN $2442-8264$

Vol. 16 No. 1, Juni 2019

Teori emanasi berasal dari Plotinus sang filosof yang berkontemplasi, pemikiran plotinus disebut "Yang Satu" (totten). Yang Satu itu adalah Yang tak Berhingga dan Absolut. Dengan lain perkatan "Yang Satu adalah Allah. Dari kesatuan yang tak berdiferensiasi itu keluarlah kebaikkan dari "Yang Satu" melalui semacam emanasi atau radiasi. ${ }^{23}$

Filsafat emanasi dalam teologi dan falsafah Islam bermaksud untuk memurnikan tauhid. Emanasi ialah teori tentang keluarnya suatu Wujud Mumkin (alam makhluk) dari Zat yang Wajib al-Wujud (Zat yang mesti adanya; Tuhan). Teori ini disebut juga " teori Urut-urutan wujud". ${ }^{24}$

Pemurnian tauhid inilah yang menimbulkan filsafat emanasi (al-Faid, pancaran). Yang Maha Esa berpikir tentang diri-Nya yang Esa, dan pemikiran merupakan daya atau energi. Karena pemikiran Tuhan tentang diri-nya merupakan daya yang dahsyat, maka daya itu menciptakan sesuatu yang diciptakan pemikiran Tuhan tentang dirinya itu adalah akal pertama atau wujud pertama yang keluar dari Tuhan. $^{25}$

\section{Falsafah Jiwa (al-nafs)}

Falsafah yang terbaik mengenai jiwa adalah pemikiran yang diberikan Ibn Sina (980-1037 M). Jiwa sebagai prinsip kehidupan, merupakan sebuah pancaran (emanasi) dari akal kecerdasan aktif. Definisi yang umum tentang jiwa adalah "Kesempurnaan yang pertama dalam tubuh organic", baik ketika ia dibentuk tumbuh dan diberi makan (seperti dalam kasus jiwa hewani), atau ketika ia memahami hal-hal universal dan bertindak berdasarkan pertumbuhan yang mendalam (seperti kasus dalam jiwa insani). ${ }^{26}$ Ibn Sina sama dengan al-Farabi ia membagi jiwa ke dalam tiga bagian.

a. Jiwa nabati (ruh nabati), ia mempunyai daya makan, tumbuh dan berkembang biak.

\footnotetext{
${ }^{23}$ P.A. Van Der Weij, dalam bukunya, Filosuf Besar Tentang Manusia, Penerj. K. Bertens, (Jakarta:Gramedia, 1998), hal. 27.

${ }^{24}$ Ahmad Hanafi, Pengantar Filsafat Islam, (Jakarta: Bulan Bintang, cet. Ke-5), hal. 92.

${ }^{25}$ Ahmad Hanafi, Ibid, hal. 93.

${ }^{26}$ Ibn Sina, An-Najat, hal. 184, 278-280, dikutip dari buku Majid Fakhri, Sejarah Filsafat Islam, (Jakarta,: Pustaka Jaya, cet. Ke-1, 1987), hal. 204.
} 


\section{FARABI}

Jurnal Pemikiran Konstruktif Bidang Filsafat dan Dakwah

ISSN $1907-0993$

E ISSN $2442-8264$

Vol. 16 No. 1, Juni 2019

b. Jiwa binatang (ruh Haywani) yang mempunyai daya gerak pindah dari satu tempat ketempat yang lain dan daya menangkap dengan panca indra.Misal; pendengaran, penglihatan, perasa, peraba, juga indra yang ada diotak. Misal: menerima pesan indra, pengingat (memory) yang mengkode (menyimpan) arti-arti.

c. Jiwa manusia (ruh Insani), mempunyai satu daya, yaitu berpikir yang disebut akal.Akal terbagi dua: Akal praktis (al-Aql al-Fa'al) yang menerima arti-arti yang berasal dari materi melalui indra pengingat yang ada dari jiwa binatang. ${ }^{27}$

3. Falsafah Kenabian (al-Nubuwwah)

Di antara manusia ada yang dianugerahi akal materil (al-aql al-hayulani) yang begitu besar dan kuat, yang oleh Ibn Sina diberi nama al-hads atau intuisi. Orang yang dianugerahi akal yang demikian, dengan tanpa melalui latihan, dengan mudah dapat berhubungan dengan Akal Kesepuluh. Oleh karena itu, orang tersebut dengan mudah dapat menerima cahaya atau wahyu dari Tuhan. Akal serupa ini mempunyai daya suci (quwwah qudsiyyah). Inilah bentuk akal tertinggi yang dapat diproleh manusia, dan terdapat hanya pada para nabi.

\section{Falsafah Wujud(al-Wujud)}

Menurut Ibnu Sina, sifat wujud-lah yang terpenting dan mempunyai kedudukan di atas segala sifat yang lain termasuk esensi (mâhiyyah) Esensi, menurut Ibnu, Sina terdapat dalam akal, sedangkan wujud terdapat di luar akal. Wujud-lah yang membuat tiap esensi yang dalam akal mempunyai kenyataan di luar akal. Tanpa wujud maka esensi tidak besar artinya, oleh karena itu wujud lebih penting dari esensi. ${ }^{28}$ Ibnu Sina dalam masalah wujud memadukan pandangan Mutakallimin, Aristoteles dan Neo-Platonisme, sehingga menjadi suatu metode tersendiri dalam menganalis wujud. Ia juga sepaham dengan gurunya Al-Fârabî bahwa al-wujûd bersifat emanasioistis yaitu dari Tuhanlah kemaujudan yang mesti adanya (Syarif, 1989:103).

\footnotetext{
${ }^{27}$ Ibnu Sina, Loc.cit, hal. 204.

${ }^{28}$ Harun Nasution, 1978, hal. 39.
} 


\section{FARABI}

Jurnal Pemikiran Konstruktif Bidang Filsafat dan Dakwah

ISSN $1907-0993$

E ISSN $2442-8264$

Vol. 16 No. 1, Juni 2019

Menurut Ibnu Sina kalau esensi dikombinasikan dengan wujud maka akan terjadi tiga kemungkinan yaitu: esensi yang tak dapat mempunyai wujud disebut 'mumtana' yaitu sesuatu yang mustahil ber-wujud (mumtana' al-wujûd). Misalnya, adanya kosmos lain sekarang ini di samping kosmos yang ada. esensi yang boleh mempunyai wujud dan boleh tidak, hal ini disebut mumkin, yaitu sesuatu yang mungkin berwujud dan mungkin juga tidak ber-wujud (mumkin alwujûd). Misalnya alam ini pada mulanya tidak ada kemudian ada dan akhirnya akan hancur menjadi tidak ada. esensi yang tidak boleh tidak mesti mempunyai wujud. Di sini, esensi tidak bisa dipisahkan dari wujud, esensi dan wujud sama dan satu. Di sini, esensi tidak dimulai oleh tidak ber-wujud dan kemudian berwujud, tetapi esensi mesti dan wajib mempunyai wujud selama-lamanya ini disebut (wâjib al-wujûd) Necessary Being), wâjib al-wujûd inilah yang mewujudkan mumkin al-wujûd dan itulah Tuhan (Nasution, 1978:40).

Selanjutnya wâjib al-wujûd ini ada dua macam, yaitu:

a. Wâjib bidhâtihi sesuatu yang kepastian wujud-Nya disebabkan oleh zat-Nya sendiri. Artinya, adanya tidak bergantung pada adanya sebab lain selain diriNya. Dalam hal ini, esensi tidak bisa dipisahkan dengan wujud, keduanya adalah satu dan wujud-Nya tidak didahului oleh tiada (ma'dum). Ia akan tetap ada selama-lamanya. Itulah Allah swt. Yang Maha Esa, Yang Hak; Ia adalah al-'Aql al-Muhaddah.

b. wâjib bigayrihi yaitu sesuatu yang kepastian wujudnya oleh zat yang lain, artinya sesuatu yang berwujud karena benda lain yang mewujudkannya. Misalnya, adanya empat karena $2+2$ atau $3+1$; adanya basah karena ada air, kebakaran disebabkan oleh api (Al-Shahrastanî, 1969:26).

\section{Tabel 1. Perbandingan filsafat emanasi}

\begin{tabular}{|l|l|}
\hline Ibnu Sina & $\begin{array}{l}\text { Dari Tuhan memancar Akal Pertama, dan dari Akal Pertama memancar Akal } \\
\text { Kedua, demikian seterusnya sampai Akal Kesepuluh. Menurut Ibn Sina akal-akal } \\
\text { itu adalah malaikat, dan Akal Pertama adalah malaikat tertinggi, kemudian Akal } \\
\text { Kesepuluh, yang mengatur bumi, adalah Jibril. } \\
\text { Menurut Ibn Sina, Akal Pertama mempunyai dua sifat, yaitu (a) sifat wajib }\end{array}$ \\
\hline
\end{tabular}


Jurnal Pemikiran Konstruktif Bidang Filsafat dan Dakwah

ISSN $1907-0993$

E ISSN $2442-8264$

Vol. 16 No. 1, Juni 2019

\begin{tabular}{|c|c|}
\hline & $\begin{array}{l}\text { wujudnya, karena ia sebagai pancaran Tuhan; dan (b) sifat mungkin } \\
\text { wujudnya, apabila dilihat dari hakekat dirinya, karena ia sebagai hasil dari } \\
\text { sesuatu yang lain. Dengan demikian Akal Pertama mempunyai tiga obyek } \\
\text { pemikiran, yaitu: Tuhan, dirinya sebagai wajib wujudnya, dan dirinya sebagai } \\
\text { mungkin wujudnya. Dari pemikiran tentang Tuhan munculah akal-akal; dari } \\
\text { pemikiran tentang dirinya yang wajib wujudnya munculah jiwa-jiwa; dan dari } \\
\text { pemikiran tentang dirinya yang mungkin wujudnya munculah langit-langit } \\
\text { (planet). Tentang Jiwa. Jiwa manusia yang memancar dari Akal Kesepuluh } \\
\text { menurut Ibn Sina dibagi menjadi tiga bagian, yaitu: (a) Jiwa Tumbuhan (al-nafs } \\
\text { al-nabatiyah), yang di dalamnya memuat daya makan, daya tumbuh, dan daya } \\
\text { berkembang biak; (b) Jiwa Binatang (al-nafs al-hayawaniyah), yang di dalamnya } \\
\text { memuat daya gerak dan daya menangkap (meliputi menangkap dari luar dan } \\
\text { menangkap dari dalam -indera bersama, representasi, imajinasi, estimasi, dan } \\
\text { rekoleksi); dan (c) Jiwa Manusia (al-nafs al-Nathiqah), yang di dalamnya memuat } \\
\text { daya praktis dan daya teoritis. } \\
\text { Daya praktis menurut Ibn Sina mempunyai kedudukan penting, karena ia akan } \\
\text { mengontrol badan manusia, sehingga hawa nafsu yang terdapat dalam badan } \\
\text { tidak menghalangi berkembangnya daya teoritis. Sementara daya teoritis } \\
\text { mempunyai empat tingkatan, yaitu: (a) Akal Materil (material intellec/al-aql al- } \\
\text { hayulani), yang semata-mata mempunyai potensi untuk berpikir; (b) intellectus in } \\
\text { habitu (al-aql bi al-malakah), yang telah mulai dilatih untuk berpikir tentang hal- } \\
\text { hal abstrak; (c) Akal Aktuil (al-aql bi al-fi'l), yang telah dapat berpikir tentang } \\
\text { hal-hal abstrak; dan (d) Akal Mustafad (al-aql al-mustafad), yang telah sanggup } \\
\text { berpikir tentang hal-hal abstrak dengan tidak perlu daya upaya, sudah terlatih } \\
\text { begitu rupa. Akal inilah yang sanggup menerima ilmu pengetahuan dari Akal } \\
\text { Kesepuluh.29 }\end{array}$ \\
\hline Al-Farabi & $\begin{array}{l}\text { Dari pemikiran akal pertama, dalam kedudukannya sebagai wujud yang wajib } \\
\text { (yang nyata) karena Tuhan, dan sebagai wujud yang mengetahui dirinya, maka } \\
\text { keluarlah akal kedua. Dari pemikiran akal pertama, dalam kedudukannya sebagai }\end{array}$ \\
\hline
\end{tabular}

\footnotetext{
${ }^{29}$ Ibnu Sina, al Najat, (Kairo : Mustafa al-Baby al-Halaby, 1938), hal 398 dan lihat juga : Muhammad Athif al-Iraqy, al-Manhaj, al-falsafat al-islamiyat, hal 219-220
} 


\section{FARABI}

Jurnal Pemikiran Konstruktif Bidang Filsafat dan Dakwah

ISSN 1907 - 0993

E ISSN $2442-8264$

Vol. 16 No. 1, Juni 2019

\begin{tabular}{|c|c|}
\hline & $\begin{array}{l}\text { wujud yang mungkin dan mengetahui dirinya maka timbullah langit pertama } \\
\text { dengan jiwa langit tersebut. Jadi dari dua objek pengetahuan yaitu dirinya dan } \\
\text { wujudnya yang mungkin, keluarlah dua macam makhluk tersebut, yaitu hendaknya } \\
\text { benda langit dan jiwanya. } \\
\text { Dari akal kedua maka timbullah akal ketiga dan langit kedua atau bintang-bintang } \\
\text { tetap beserta jiwanya dengan cara yang sama seperti yang terjadi pada akal } \\
\text { pertama. } \\
\text { Dari akal ketiga keluarlah akal keempat dan planet Saturnus (Zuhal), juga beserta } \\
\text { jiwanya. } \\
\text { Dari akal keempat keluarlah akal kelima dan planet Yupiter (al-Masy - tara), } \\
\text { beserta jiwanya. } \\
\text { Dari akal kelima keluarlah akal keenam dan planet Mars (Marilah), beserta } \\
\text { jiwanya. } \\
\text { Dari akal keenam keluarlah akal ketujuh dan Matahari (as-Syams), beserta } \\
\text { jiwanya. } \\
\text { Dari akal ketujuh keluarlah akal kedelapan dan planet Venus (az- Zuharah), } \\
\text { beserta jiwanya. } \\
\text { Dari akal kedelapan keluarlah akal kesembilan dan planet Mercurius (U'tarid), } \\
\text { beserta jiwanya. } \\
\text { Dari akal kesembilan keluarlah akal kesepuluh bulan (Qomar) } \\
\text { Dengan demikian maka dari satu akal keluarlah satu akal pula dan satu planet } \\
\text { beserta jiwanya. Dari akal kesepuluh sesuai dengan dua seginya yaitu wajib-al- } \\
\text { wujud karena Tuhan maka keluarlah manusia beserta jiwanya dan dari segi dirinya } \\
\text { yang merupakan wujudnya yang mungkin maka keluarlah unsur empat dengan } \\
\text { perantaraan benda-benda langit. }{ }^{30}\end{array}$ \\
\hline $\begin{array}{c}\text { Ibn } \\
\text { Miskawaihi }\end{array}$ & $\begin{array}{l}\text { Entitas pertama yang memancarkan dari Allah ialah 'aql Fa'al' (akal aktif). Akal } \\
\text { aktif ini timbullah jiwa dan dengan perantaraan jiwa pula timbullah planet (al- } \\
\text { falak). Pancaran yang terus-menerus dari Allah dapat memelihara tatanan alam ini. } \\
\text { Andaikan Allah menahan pancaran-Nya, maka akan terhenti kemajuan dalam alam }\end{array}$ \\
\hline
\end{tabular}

\footnotetext{
${ }^{30}$ Ahmad Hanafi, Op.cit, hal. 94
} 


\section{FARABI}

Jurnal Pemikiran Konstruktif Bidang Filsafat dan Dakwah

ISSN 1907 - 0993

E ISSN $2442-8264$

Vol. 16 No. 1, Juni 2019

\begin{tabular}{|c|c|}
\hline & $\begin{array}{l}\text { ini. Dari Akal Aktif ini timbullah jiwa dan dengan perantaraan jiwa pula timbullah } \\
\text { planet. Pelimpahan atau pemancaran yang terus menerus dari Allah dapat } \\
\text { memelihara tatanan didalam alam ini. Andaikan Allah menahan pancaran-Nya, } \\
\text { maka akan berhenti kemaujudan dalam alam ini. Berikut perbedaan emanasi antara } \\
\text { Al-Farabi dan Ibnu Miskawaih, yaitu: } \\
\text { 1) Bagi Ibnu Miskawaih, Allah menjadikan alam ini secara pancaran (emanasi) } \\
\text { dari tiada menjadi ada. Sementara itu, menurut Al-Farabi alam dijadiakan Tuhan } \\
\text { secara pancaran (emanasi) dari sesuatu atau bahan yang sudah ada menjadi ada. } \\
\text { 2) Bagi Ibnu Miskawaih ciptaan Allah yang pertama ialah Akal Aktif. } \\
\text { Sementara bagi Al-Farabi ciptaan Allah yang pertama ialah Akal pertama dan Akal } \\
\text { Aktif adalah akal kesepuluh. }{ }^{31}\end{array}$ \\
\hline & $\begin{array}{l}\text { Allah adalah Pencipta dan Mutlak Esa. Dengan kemauan sendiri Allah } \\
\text { menciptakan Akal Pertama atau Akal aktif secara emanasi. Kemudian, Allah } \\
\text { menciptakan jiwa dengan perantaraan akal. Selanjutnya, Allah menciptakan materi } \\
\text { pertama. Dengan demikian, kalau Allah qadim, lengkap dan sempurna, maka Akal } \\
\text { Pertama ini juga demikian halnya. Pada Akal Pertama lengkap segala potensi yang } \\
\text { akan muncul pada wujud berikutnya. Sementara jiwa terciptanya secara emanasi } \\
\text { dengan perantaraan akal, maka jiwa qadim dan lengkap tetapi tidak sempurna. } \\
\text { Demikian juga halnya materi pertama karena terciptanya secara emanasi dengan } \\
\text { perantaraan jiwa, maka materi pertama adalah qadim, tidak lengkap dan tidak } \\
\text { sempurna. Jadi, Allah tidak berhubungan dengan alam materi secara langsung } \\
\text { sehingga kemurnian tauhid dapat terpelihara dengan sebaik-baiknya. Ringkasnya } \\
\text { rangkaian proses emanasi tersebut sebagai berikut : Akal Aktif atau Akal } \\
\text { Pertama (Al-'Aql Al-Fa'al), Jiwa Universal (An-Nafs Al-Kulliyyat), Materi } \\
\text { Pertama (Al-Hayula Al-Ula), Alam Aktif (At-Thabi'at Al-Fa'ilat), Materi Absolut } \\
\text { dan Materi kedua (Al-Jism Al-Muthlaq), Alam Planet-Planet ('Alam Al- } \\
\text { Aflak),Unsur-Unsur alam terendah ('Anashir Al-'Alam As-Sufla)yaitu air, tanah, } \\
\text { udara dan api. Materi gabungan, yang terdiri dari mineral, tumbuh-tumbuhan dan }\end{array}$ \\
\hline
\end{tabular}

${ }^{31}$ Sirajuddin Zar, Filsafat Islam: Filosof Dan Filsafatnya, (Jakarta: PT RajaGrafindo Persada, 2004), hal. 131. 


\section{FARABI}

Jurnal Pemikiran Konstruktif Bidang Filsafat dan Dakwah

ISSN $1907-0993$

E ISSN $2442-8264$

Vol. 16 No. 1, Juni 2019

hewan. Sementara itu manusia termasuk kedalam kelompok hewan, tetapi hewan yang berbicara dan berpikir. ${ }^{32}$

\section{PENUTUP}

Ibnu Sina memiliki pemikiran keagamaan yang mendalam. Pemahamannya mempengaruhi pandangan filsafatnya. Ketajaman pemikirannya dan kedalaman keyakinan keagamaannya mewarnai alam pikirannya. Ibnu Sina sependapat dengan al-Farabi mengenai filsafat jiwanya. Ibnu Sina dapat berpendapat bahwa akal pertama mempunyai dua sifat, yaitu: Sifat wajib wujudnya, sebagai pancaran dari Allah dan Sifat mungkin wujudnya, jika ditinjau dari hakikat dirinya.

Sifat seseorang bergantung pada jiwa mana dari ketiga macam jiwa yaitu tumbuh-tumbuhan, binatang dan manusia yang berpengaruh pada dirinya. Jika jiwa tumbuhan atau hewan mempengaruhi seseorang maka orang itu dapat menyerupai binatang, tetapi jika jiwa manuisia yang mempunyai pengaruh atas dirinya, maka orang itu dekat menyerupai malaekat dan dekat dengan kesempurnaan.

Menurut Ibnu Sina bahwa alam ini diciptakan dengan jalan emanasi (memancar dari Tuhan). Tuhan adalah wujud pertama yang immateri dan proses emanasi tersebut memancar segala yang ada. Tuhan adalah wajibul wujud (jika tidak ada menimbulkan mustahil), beda dengan mumkinul wujud (jika tidak ada atau ada menimbulkan tidak mustahil).

Pemikiran tentang kenabian Ibnu Sina menjelaskan bahwa nabi merupakan manusia yang paling unggul dari filosof, karena nabi memiliki akal yang sempurna tanpa latihan, sedangkan filosof mendapatkannya dengan usaha yang keras.

\footnotetext{
${ }^{32}$ Ibid,
} 


\section{FARABI}

Jurnal Pemikiran Konstruktif Bidang Filsafat dan Dakwah

ISSN $1907-0993$

E ISSN $2442-8264$

Vol. 16 No. 1, Juni 2019

\section{DAFTAR PUSTAKA}

Ahmad Hanafi, Pengantar Filsafat Islam, cet. Ke-5 (Jakarta: Bulan Bintang, Hanafi, 1976).

Ahmad Daudy, Kuliah FilsafatIslam, (Jakarta, Bulan Bintang, cet. Ke-3, 1992)

Abu Ahmadi, Filsafat Islam, Thoha Putra, Semarang, 1982

Ahmad Fuad al- Ahwani, Filsafat Islam (Jakarta: Pustaka Firdaus, 1997).

Anawati, Essai de Bibliographhie Avicenniene,

Didin Saifuddin, Zaman Keemasan Islam: Rekontruksi Sejarah Imperium Dinasti Abbasiyah.

Ibnu Sina, al Najat, (Kairo : Mustafa al-Baby al-Halaby, 1938)

Muhammad Tolhah Hasan, Dinamika Pemikiran tentang Pendidikan Islam (Jakarta: Lantabora Press, 2006).

Hasyimsyah Nasution, Filsafat Islam, (Jakarta: Gaya Media Pratama, 1999).

Husain Heriyanto, Menggali Nalar Saintifik Peradaban Islam.

Muhammad Nur Effendi, Cendekiawan Muslim: Pembina Tamadun dan Kecemerlangan Umat, Cet. 1.

M. Saeed Sheikh, Islamic Philosophy, (London: The Octagon Press Ltd, 1982).

Muhammad Nur Effendi, Cendekiawan Muslim: Pembina Tamadun dan Kecemerlangan Umat.

Majid Fakhri, Sejarah Filsafat Islam, (Jakarta : Pustaka Jaya, 1986).

M. Natsir , "Islam dan Kebudayaan” Jurnal Kapita Selekta, Cet. III. (Jakarta: Bulan Bintang, 1973).

P.A. Van Der Weij, dalam bukunya, Filosuf Besar Tentang Manusia, Penerj. K. Bertens,(Jakarta:Gramedia, 1998).

Pembinaan Perguruan Tinggi Agama IAIN Ar-Raniry, Pengantar filsafat...,

Philip K.. Hitti, History of The Arab, (ed). X (Great Britain: Oxford University Press, 1974).

Sirajuddin Zar, Filsafat Islam: Filosof Dan Filsafatnya, (Jakarta: PT Raja Grafindo Persada, 2004),

Saharawati Mahmouddin, Sistem Kedokteran Islam: Studi Konsep Kesehatan Mental Ibnu Sina.

Seyyed Hossein Nasr, Tiga Madzhab Utama Filsafat Islam. 